\title{
Urocortin III-Immunoreactive Projections in Rat Brain: Partial Overlap with Sites of Type 2 Corticotrophin-Releasing Factor Receptor Expression
}

\author{
Chien Li, ${ }^{1}$ Joan Vaughan, ${ }^{1}$ Paul E. Sawchenko, ${ }^{2}$ and Wylie W. Vale ${ }^{1}$ \\ 1The Clayton Foundation Laboratories for Peptide Biology and 'Laboratory of Neuronal Structure and Function, The Salk \\ Institute for Biological Studies, La Jolla, California 92037
}

Urocortin (Ucn) III, or stresscopin, is a new member of the corticotropin-releasing factor (CRF) peptide family identified in mouse and human. Pharmacological studies showed that Ucn III is a high-affinity ligand for the type 2 CRF receptor (CRF-R2). To further understand physiological functions the peptide may serve in the brain, the distribution of Ucn III neurons and fibers was examined by in situ hybridization and immunohistochemistry in the rat brain. Ucn III-positive neurons were found predominately within the hypothalamus and medial amygdala. In the hypothalamus, Ucn III neurons were observed in the median preoptic nucleus and in the rostral perifornical area lateral to the paraventricular nucleus. The Ucn III fibers were distributed mainly in the hypothalamus and limbic structures. Hypothalamic regions that were innervated prominently by Ucn III fibers included the ventromedial nucleus, medial preoptic nucleus,

The corticotropin-releasing factor (CRF) family consists of a growing number of peptides identified in a variety of species (Perrin and Vale, 1999). In addition to CRF, three CRF-related peptides, urocortin (Ucn) (Vaughan et al., 1995), Ucn II (Reyes et al., 2001), and Ucn III (Lewis et al., 2001), have been identified in humans, rodents, and other mammalian species. Human Ucn III, also known as stresscopin (Hsu and Hsueh, 2001), is the latest addition to this family. Sequence analysis shows that the predicted human and mouse Ucn III mature peptides are 90\% identical and closely related to a urocortin-related peptide identified originally in pufferfish (Brunner et al., 2000) but exhibit less relatedness to the other mammalian family members (Lewis et al., 2001). In vitro binding studies showed that both human and mouse Ucn III bound the type 2 CRF receptor (CRF-R2) with high affinity but did not bind to the other known receptor for the family, CRF-R1 (Hsu and Hsueh, 2001; Lewis et al., 2001). Accordingly, Ucn III stimulated cAMP production in cells expressing CRF-R2 but not in cells expressing CRF-R1 (Hsu and Hsueh, 2001; Lewis et al., 2001). These data identify Ucn III as a high-affinity ligand for CRF-R2.

Received Aug. 23, 2001; revised Oct. 24, 2001; accepted Nov. 9, 2001

This work was supported by National Institutes of Health Program Project DK-26741, The Kleberg Foundation, The Adler Foundation, The Foundation for Medical Research, Inc., and The Foundation for Research. W.W.V. is a FFR Senior Investigator. P.E.S. is an FMR, Inc. Senior Investigator. C.L. is supported by National Research Service Award MH-12654. We thank J. Gulyas and J. Rivier who made the peptides used in the study. We also thank Dr. P. Jamison and B. Henry for comments on this manuscript.

Correspondence should be addressed to Dr. Wylie W. Vale, The Clayton Foundation for Peptide Biology Laboratories, The Salk Institute for Biological Studies, 10010 North Torrey Pines Road, La Jolla, CA 92037. E-mail:vale@salk.edu.

Copyright $(\odot 2002$ Society for Neuroscience $0270-6474 / 02 / 220991-11 \$ 15.00 / 0$ and ventral premammillary nucleus. Outside the hypothalamus, the densest projections were found in the intermediate part of the lateral septum, posterior division of the bed nucleus stria terminalis, and the medial nucleus of the amygdala. Several major Ucn III terminal fields identified in the present study, including the lateral septum and the ventromedial hypothalamus, are known to express high levels of CRF-R2. Thus, these anatomical data strongly support the notion that Ucn III is an endogenous ligand for CRF-R2 in these areas. These results also suggest that Ucn III is positioned to play a role in mediating physiological functions, including food intake and neuroendocrine regulation.

Key words: urocortin; CRF; perifornical hypothalamus; medial amygdala; ventromedial hypothalamus; CRF-R2

In brain, CRF-R2 is expressed in discrete regions, including the lateral septum and ventromedial hypothalamus in the forebrain and dorsal raphe and nucleus of the solitary tract in the hindbrain (Chalmers et al., 1995; Van Pett et al., 2000). Central CRF-R2 has been implicated as playing important regulatory roles in feeding (Spina et al., 1996; Makino et al., 1998; Nishiyama et al., 1999; Ohata et al., 2000), gastric motility (Martinez et al., 1997; Martinez and Tache, 2001), anxiety (Bale et al., 2000; Coste et al., 2000; Kishimoto et al., 2000), and stress-associated learning (Radulovic et al., 1999). However, an important question that has remained unresolved is the ligand responsible for the activation of CRF-R2 in the brain. Ucn was originally proposed to be an endogenous ligand for CRF-R2 in the brain based on its high affinity for the receptor (Vaughan et al., 1995). However, anatomical data have shown that most major sites of CRF-R2 expression are poorly innervated by Ucn-containing projections (Kozicz et al., 1998; Bittencourt et al., 1999), suggesting that additional family peptides, such as Ucn II or Ucn III, might serve as endogenous ligand for CRF-R2 in some brain regions.

To further characterize the distribution of Ucn III in the brain and to highlight potential functional associations, we performed immunohistochemical studies examining the distribution of Ucn III neurons and fibers in the rat brain. The wide distribution of Ucn III fibers observed in the present study suggests that the peptide may be involved in a variety of physiological functions. In addition, the presence of Ucn III fibers in many brain regions that also express CRF-R2 strongly suggested that Ucn III could function as an endogenous ligand for CRF-R2. 
Table 1. Competition characteristics of Ucn III immunoreactivity in rat brain

\begin{tabular}{|c|c|c|c|c|c|}
\hline \multirow[b]{2}{*}{ Competing peptide } & \multicolumn{5}{|c|}{ Concentrations $(\mu \mathrm{M})$} \\
\hline & 3 & 10 & 30 & 100 & 300 \\
\hline Mouse Ucn III & - & - & - & - & - \\
\hline Human Ucn III & - & - & - & - & - \\
\hline Mouse Ucn II & ++++ & ++++ & ++++ & ++++ & ++++ \\
\hline Rat Ucn & ++++ & ++++ & ++++ & ++++ & ++++ \\
\hline Human/rat-CRF ${ }^{a}$ & ++++ & ++++ & ++++ & ++++ & ++++ \\
\hline Fish urotensin I & ++++ & ++++ & ++++ & ++++ & ++++ \\
\hline
\end{tabular}

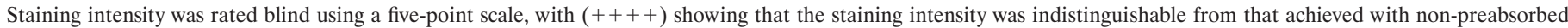
antiserum and $(-)$ indicating a complete absence of staining.

${ }^{a}$ Ucn III staining in the external zone of the median eminence was blocked by preabsorption with CRF at all concentrations tested.

\section{MATERIALS AND METHODS}

Perfusion and fixation. Adult male Sprague Dawley rats weighing 275-350 $\mathrm{gm}$ were used for the present studies. To facilitate the visualization of Ucn III cell body by immunohistochemistry, some animals $(n=5)$ received $10 \mu \mathrm{l}$ of colchicine $(10 \mu \mathrm{g} / \mu \mathrm{l}$ in $0.9 \%$ saline $)$ into a lateral ventricle $2 \mathrm{~d}$ before perfusion. Animals were anesthetized with an overdose of choral hydrate $(1 \mathrm{gm} / \mathrm{kg}$ body weight, i.p.) and perfused transcardially with $150 \mathrm{ml}$ of saline, followed by $350 \mathrm{ml}$ of $4 \%$ paraformaldehyde in borate buffer, $\mathrm{pH}$ 9.5. The brains were removed and post-fixed in $25 \%$ sucrose in the same fixative at $4^{\circ} \mathrm{C}$ overnight. They were then quickly frozen in dry ice and sectioned at $25 \mu \mathrm{m}$ using a sliding microtome and stored in cryoprotectant at $-20^{\circ} \mathrm{C}$ until use. All animal procedures were approved by the Salk Institute Institutional Animal Care and Use Committee.

Antiserum and controls. Anti-Ucn III serum (PBL \#6570) was raised in rabbit against synthetic human GlyTyr-Ucn III conjugated to human $\alpha$-globulins via bisdiazotized benzidine. To test the specificity of the antiserum for immunohistochemistry, the antiserum (1:200) was preincubated for $24 \mathrm{hr}$ at $4^{\circ} \mathrm{C}$ with $0-300 \mu \mathrm{M}$ synthetic human or mouse Ucn III, mouse Ucn II, rat Ucn, human-rat CRF, or fish urotensin I before incubation with brain sections.

Immunohistochemistry. Brain sections were removed from cryoprotectant and rinsed in $0.05 \mathrm{M}$ potassium PBS (KPBS), followed by treatment with $1 \% \mathrm{NaBH}_{4}-\mathrm{KPBS}_{\mathrm{N}}$ solution. Sections were incubated in rabbit anti-Ucn III antiserum (1:19,000 final dilution) in KPBS with $0.4 \%$ Triton X-100 at room temperature for $1 \mathrm{hr}$ and then at $4^{\circ} \mathrm{C}$ for $48 \mathrm{hr}$. The tissues were then rinsed in KPBS and incubated in biotinylated donkey anti-rabbit IgG (1:700; Jackson ImmunoResearch, West Grove, PA) in KPBS with $0.4 \%$ Triton X-100 for $1 \mathrm{hr}$ at room temperature. This was followed by another $1 \mathrm{hr}$ incubation at room temperature in avidinbiotin complex solution (Vectastain ABC Elite kit; Vector Laboratories, Burlingame, CA). The antibody-peroxidase complex was visualized with a mixture of nickel sulfate $(25 \mathrm{mg} / \mathrm{ml}), 3,3$-diaminobenzidine $(0.2 \mathrm{mg}$ / $\mathrm{ml})$, and $3 \% \mathrm{H}_{2} \mathrm{O}_{2}(0.83 \mu \mathrm{l} / \mathrm{ml})$ in $175 \mathrm{~mm}$ sodium acetate solution. When the staining had reached the appropriate intensity, the tissue was rinsed in KPBS and mounted on gelatin-coated glass slides. Slides were dehydrated through graded alcohols, cleared in xylenes, and coverslipped with DPX mountant (Electronic Microscope Science, Fort Washington, PA). Adjacent series of brain sections were processed for Nissl staining for reference purposes.

In situ hybridization. Animals were quickly decapitated, and the brains were removed and frozen in dry ice. Coronal sections ( $20 \mu \mathrm{m}$ thick) were cut on a cryostat, thaw-mounted onto glass slides, and stored at $-80^{\circ} \mathrm{C}$ until use. An antisense cRNA probe was transcribed from a linearized $528 \mathrm{bp}$ mouse Ucn III cDNA and labeled with $\left[{ }^{35}\right.$ S]UTP (PerkinElmer Life Sciences, Emeryville, CA). The specific activity of the probe was $\sim 1-3 \times 10^{8} \mathrm{dpm} / \mu \mathrm{g}$ cRNA. The saturating concentration for the probe used in the assay was $0.3 \mu \mathrm{g} / \mathrm{ml} \cdot \mathrm{Kb}$.

The procedure for in situ hybridization has been described previously (Li et al., 1998). Briefly, the brain sections were fixed in $4 \%$ paraformaldehyde and treated with $0.25 \%$ acetic anhydride in $0.1 \mathrm{~m}$ triethanolamine, $\mathrm{pH} 8.0$, followed by a rinse in $2 \times \mathrm{SSC}$, dehydrated through a graded series of alcohols, delipidated in chloroform, rehydrated through a second series of alcohols, and then air dried. The slides were exposed to the cRNA probe overnight in humidified chambers at $55^{\circ} \mathrm{C}$. After incubation, the slides were washed in SSC of increasing stringency, in RNase, and then in $0.1 \times \mathrm{SSC}$ at $63^{\circ} \mathrm{C}$, dehydrated through a graded series of alcohols, and dried. Slides were dipped in NTB-2 emulsion (Eastman Kodak, Rochester, NY), exposed for $10 \mathrm{~d}$ at $4^{\circ} \mathrm{C}$, and developed. After development, the slides were counterstained with cresyl violet.

Imaging. Slides were examined using a Leica (Nussloch, Germany) light microscope, and images were captured onto Kodak Ektachrome $64 \mathrm{~T}$ (tungsten) films. The films were scanned into a computer using a Nikon (Tokyo, Japan) LS1000 $35 \mathrm{~mm}$ film scanner. The images were cropped and adjusted to balance brightness and contrast in Adobe Photoshop (version 5.5; Adobe Systems, San Jose, CA) before import into Canvas (version 6.0) for assembly into plates. Schematic mapping of Ucn III neurons and fibers in brain sections was performed in Adobe Illustrator (version 7.01) using coronal brain plates from the rat brain atlas of Swanson (Swanson, 1999) as templates. The brain plates were then imported into Canvas for reordering.

\section{RESULTS}

\section{Antiserum specificity}

To evaluate the specificity of the anti-Ucn III serum, the antiserum was preincubated with synthetic peptides of varying concentrations before use for immunohistochemistry. The results of the competition studies are summarized in Table 1. Staining for Ucn III cells and fibers in the brain was completely abolished by preincubation of the antiserum with synthetic mouse or human Ucn III at concentrations in the low micromolar range [Fig. 1, Tables 1, 2 (Table 2 includes a list of abbreviations used in the figures)]. Ucn, Ucn II, and urotensin I each failed to block the Ucn III-specific staining, even at the highest concentration used (Table 1). CRF was also ineffective in competing Ucn III-specific staining in all areas examined, except the external zone of the median eminence, in which the Ucn III immunoreactivity was blocked by preabsorption with low concentration of CRF. Consequently, Ucn III antiserum was routinely absorbed with $30 \mu \mathrm{M}$ CRF before use to eliminate the cross-reactivity observed in the median eminence.

\section{Distribution of Ucn III cell bodies}

Both immunohistochemical and hybridization histochemical methods detected Ucn III-positive neurons in several restricted areas in the brain. The distribution of Ucn III-IR neurons identified by immunohistochemistry in colchicine-treated rats was similar to that identified by in situ hybridization (Figs. 2, 3), further validating the specificity of the Ucn III antiserum used in the present study.

In agreement with our previous hybridization histochemical analysis (Lewis et al., 2001), Ucn III neurons were found in discrete subcortical regions of the brain, including the preoptic region, hypothalamus, and amygdala. In the hypothalamus, labeled neurons were localized in two major areas. The first group of Ucn III neurons was found in the median preoptic nucleus 


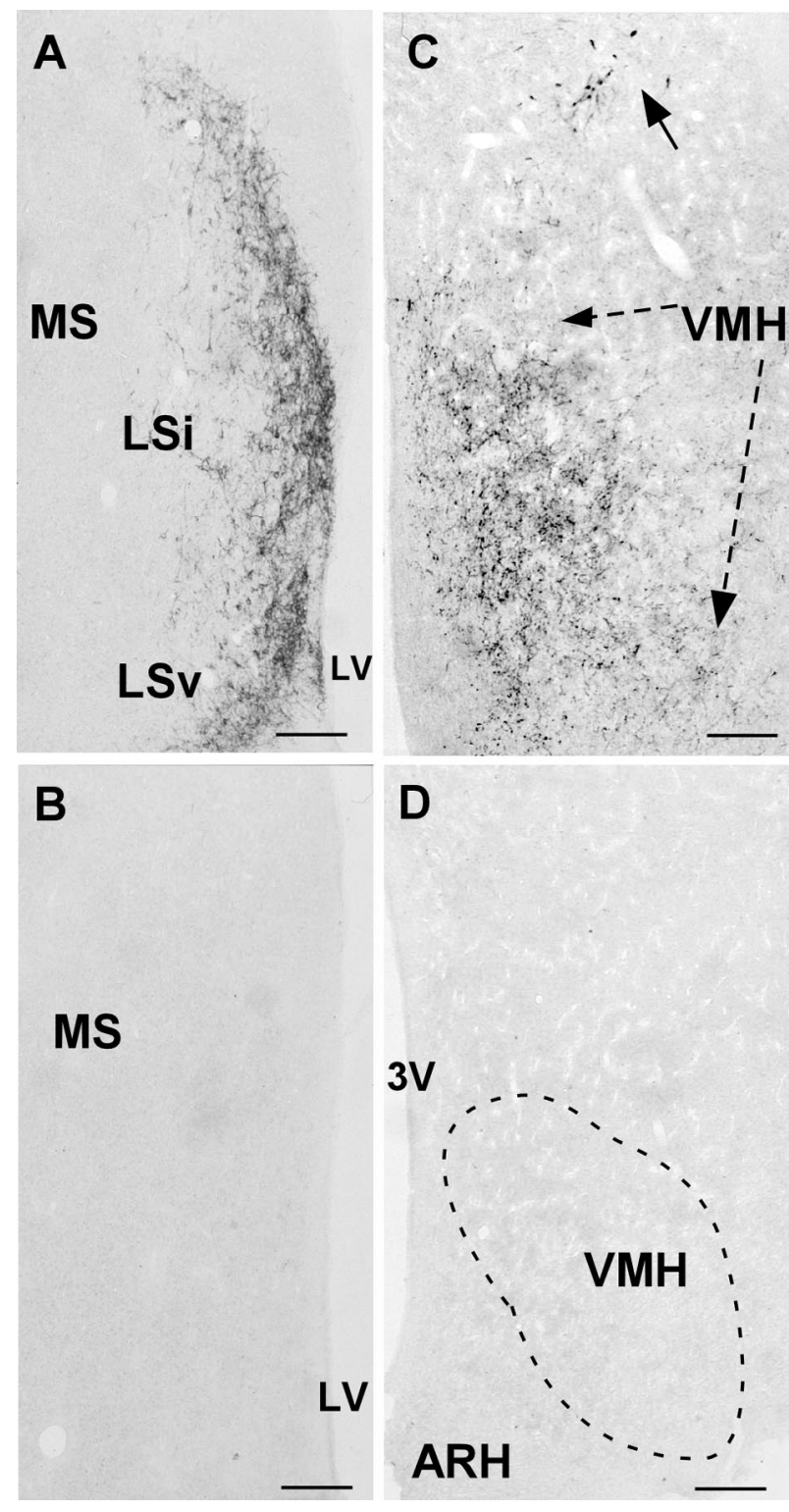

Figure 1. Representative photomicrographs showing Ucn III immunostaining in the $\operatorname{LS}(A, B)$ and VMH $(C, D)$ with $(B, D)$ or without $(A, C)$ preabsorbing the anti-Ucn III serum with $3 \mu \mathrm{M}$ human Ucn III before use. The dense crescent-shaped Ucn III terminal field in the LS $(A)$ and abundant fibrous staining in the VMH $(C)$ were effectively blocked by preabsorption with Ucn III $(B, D)$. Note that some Ucn III-positive cells (arrow) in the dorsal hypothalamic area in $C$ were also blocked $(D)$. Scale bars, $50 \mu \mathrm{m}$.

(MePO) lining the rostral margin of the third ventricle (Fig. $2 A, B)$, with a few lightly labeled cells found in the ventrolateral part of the medial preoptic area and also in the lateral preoptic area. The second group of Ucn III neurons was located in a poorly defined area closely associated with the fornix (Fig. $2 C-F$ ) at the level of paraventricular nucleus (PVH). The cell group extended rostrally into several subnuclei of the posterior division of the bed nucleus of stria terminalis (BST), with a few scattered cells seen at the caudal part of the anterior division. Intensely stained cells were observed mostly in the perifornical area between the fornix and the PVH, with a few cells found in the anterior parvicellular (Fig. 2C,D) and the magnocellular (Fig. $2 E, F)$ parts of the PVH. More caudally, the cell group remained closely lateral to the PVH, whereas the fornix gradually shifted laterally toward the lateral hypothalamic area. A few scattered cells were found in the rostral part of the dorsomedial hypothalamic area. No Ucn III cells were seen within the hypothalamus caudal to the level of the compact zone of the dorsomedial hypothalamus. Scattered Ucn III neurons were present in the periventricular zone along the third ventricle and in the area dorsal to the supraoptic nucleus.

Outside the hypothalamus, most of the Ucn III neurons were found in the amygdala, in which Ucn III neurons were concentrated in the dorsal division of the medial nucleus of the amygdala (MEA). In the anterodorsal division of the MEA, Ucn III cells were found closely associated with the optic tract (Fig. $3 A, B$ ). In the posterodorsal part of the MEA, the cell population shifted away from the optic tract and was concentrated in the lateral part of the MEA. Scattered cells were also observed in the posterior cortical nucleus of the amygdala and the amygdalohippocampal transition area. In the brainstem, Ucn III neurons were found in the auditory complex, including the superior paraolivary nucleus (Fig. $3 E, F$ ) and extending to the nucleus of trapezoid body.

\section{Distribution of Ucn III fibers}

Immunohistochemical staining using the Ucn III antiserum revealed staining of axons and varicosities in the subcortical regions, including several limbic structures and the hypothalamus, although no fibers were found in the cortex and the cerebellum. The distribution of Ucn III-IR fibers in the brain is illustrated in Figure 4 at several representative levels.

In the hypothalamus, the densest Ucn III-IR fibers were found in the ventromedial nucleus (VMH), the predominate site of CRF-R2 expression within the hypothalamus (Chalmers et al., 1995; Van Pett et al., 2000). An extremely high concentration of Ucn III-IR fibers was observed in the dorsomedial part of the VMH (Fig. 5B), whereas the central and ventrolateral parts of the nucleus received a somewhat less dense innervation. This pattern was most salient at caudal levels of the VMH (Fig. 5C). Abundant Ucn III-IR fibers were also found in the area between the VMH and the arcuate nucleus and extended into the lateral part of the arcuate nucleus proper (Fig. $5 B$ ). Abundant Ucn III fibers and terminals also innervated the rostral part of the arcuate nucleus and extended into the retrochiasmatic area (Fig. $5 E$ ). Very few fibers were found in the dorsomedial nucleus (Fig. $5 B, C$ ) and the lateral hypothalamus (Fig. 4). In the anterior hypothalamic region, abundant Ucn III-IR fibers were observed in the rostral perifornical area (Fig. 5D) surrounding the Ucn III neurons. Very few fibers terminated in the anterior hypothalamus, the supraoptic nucleus, and neurosecretory subdivisions of the PVH (Fig. $5 D)$. In the preoptic area, Ucn III-IR fibers were found predominately in the medial preoptic nucleus (Fig. $5 A$ ), with scant fibers observed in the organum vasculosum of lamina terminalis, the subfornical organ, and the MePO. In the posterior hypothalamic region, Ucn III-IR fibers coursed through the supramammillary nucleus and terminated in the ventral premammillary nucleus (Fig. $5 G$ ). Scattered fibers were found in posterior hypothalamus. In the median eminence, Ucn III-IR fibers were seen only in the internal zone (Fig. $5 F$ ).

Outside the hypothalamus, Ucn III-IR fibers were most abundant in discrete aspects of limbic structures, including the lateral septum (LS), the posterior division of the BST, and the medial amygdala, areas also known to express high levels of CRF-R2 (Chalmers et al., 1995; Van Pett et al., 2000). In the LS, an exceedingly dense Ucn III terminal field in a crescent-shaped 


\begin{tabular}{|c|c|c|c|}
\hline $3 \mathrm{~V}$ & Third ventricle & GPm & Globus pallidus, medial segment \\
\hline $4 \mathrm{~V}$ & Fourth ventricle & IA & Intercalated nuclei amygdala \\
\hline aco & Anterior commissure & IAM & Interanteromedial nucleus thalamus \\
\hline $\mathrm{AD}$ & Anterior nucleus of thalamus & $\mathrm{iCe}$ & Inferior colliculus, external nucleus \\
\hline AHA & Anterior hypothalamic area & Int & Internal capsule \\
\hline $\mathrm{AHN}$ & Anterior hypothalamic nucleus & $\mathrm{LC}$ & Locus coeruleus \\
\hline AHNa & Anterior hypothalamic nucleus, anterior part & LDT & Laterodorsal tegmental nucleus \\
\hline AHNc & Anterior hypothalamic nucleus, central part & LGd & Lateral geniculate complex, dorsal part \\
\hline $\mathrm{AHNp}$ & Anterior hypothalamic nucleus, posterior part & LGvl & Lateral geniculate complex, ventrolateral part \\
\hline Amd & Anteromedial nucleus thalamus, dorsal part & $\mathrm{LH}$ & Lateral habenula \\
\hline $\mathrm{AQ}$ & Cerebral aqueduct & LHA & Lateral hypothalamic area \\
\hline ARH & Arcuate nucleus of hypothalamus & 11 & Lateral lemniscus \\
\hline AT & Anterior tegmental nucleus & LM & Lateal mammillary nucleus \\
\hline AV & Anteroventral nucleus thalamus & LPO & Lateral preoptic area \\
\hline AVP & Anteroventral preoptic nucleus & LSi & Lateral septal nucleus, intermediate part \\
\hline $\mathrm{B}$ & Barrington's nucleus & LSv & Lateral septal nucleus, ventral part \\
\hline BLAa & Basolateral nucleus amygdala, anterior part & LV & Lateral ventricle \\
\hline BLAp & Basolateral nucleus amygdala, posterior part & MA & Magnocellular preoptic nucleus \\
\hline ВМАа & Basomedial nucleus amygdala, anterior part & MD & Mediodorsal nucleus thalamus \\
\hline BST & Bed nucleus of stria terminalis & MDc & Mediodorsal nucleus thalamus, central part \\
\hline BSTad & $\begin{array}{l}\text { Bed nucleus of stria terminalis, anterior divi- } \\
\text { sion, anterodorsal area }\end{array}$ & $\begin{array}{l}\text { ME } \\
\text { MEA }\end{array}$ & $\begin{array}{l}\text { Median eminence } \\
\text { Medial nucleus amygdala }\end{array}$ \\
\hline BSTal & $\begin{array}{l}\text { Bed nucleus of stria terminalis, anterior divi- } \\
\text { sion, anterolateral area }\end{array}$ & $\begin{array}{l}\text { MEAad } \\
\text { MEApv }\end{array}$ & $\begin{array}{l}\text { Medial nucleus amygdala, anterodorsal part } \\
\text { Medial nucleus amygdala, posterodorsal part }\end{array}$ \\
\hline BSTdl & $\begin{array}{l}\text { Bed nucleus of stria terminalis, posterior divi- } \\
\text { sion, dorsal nucleus }\end{array}$ & $\begin{array}{l}\mathrm{MePO} \\
\mathrm{MH}\end{array}$ & $\begin{array}{l}\text { Median preoptic nucleus } \\
\text { Medial habenula }\end{array}$ \\
\hline BSTif & $\begin{array}{l}\text { Bed nucleus of stria terminalis, posterior divi- } \\
\text { sion, interfascicular nucleus }\end{array}$ & $\begin{array}{l}\mathrm{ml} \\
\mathrm{mlf}\end{array}$ & $\begin{array}{l}\text { Medial lemniscus } \\
\text { Medial longitudinal fascicle }\end{array}$ \\
\hline BSTmg & $\begin{array}{l}\text { Bed nucleus of stria terminalis, anterior divi- } \\
\text { sion, magnocellular nucleus }\end{array}$ & $\begin{array}{l}\text { MPN } \\
\text { MPNl }\end{array}$ & $\begin{array}{l}\text { Medial preoptic nucleus } \\
\text { Medial preoptic nucleus, lateral part }\end{array}$ \\
\hline BSTpr & $\begin{array}{l}\text { Bed nucleus of stria terminalis, posterior divi- } \\
\text { sion, principle nucleus }\end{array}$ & $\begin{array}{l}\text { MPO } \\
\text { MRN }\end{array}$ & $\begin{array}{l}\text { Medial preoptic area } \\
\text { Mesencephalic reticular nucleus }\end{array}$ \\
\hline BSTrh & $\begin{array}{l}\text { Bed nucleus of stria terminalis, anterior divi- } \\
\text { sion, rhomboid nucleus }\end{array}$ & $\begin{array}{l}\text { MS } \\
\text { MT }\end{array}$ & $\begin{array}{l}\text { Medial septal nucleus } \\
\text { Medial terminal nucleus accessory optic tract }\end{array}$ \\
\hline BSTtr & $\begin{array}{l}\text { Bed nucleus of stria terminalis, posterior divi- } \\
\text { sion, transverse nucleus }\end{array}$ & $\begin{array}{l}\mathrm{mtV} \\
\mathrm{MV}\end{array}$ & $\begin{array}{l}\text { Mesencephalic tract of the trigeminal nerve } \\
\text { Medial vestibular nucleus }\end{array}$ \\
\hline BSTv & $\begin{array}{l}\text { Bed nucleus of stria terminalis, posterior divi- } \\
\text { sion, ventral nucleus }\end{array}$ & $\begin{array}{l}\mathrm{NB} \\
\mathrm{NDB}\end{array}$ & $\begin{array}{l}\text { Nucleus brachium inferior colliculus } \\
\text { Nucleus of the diagonal band }\end{array}$ \\
\hline CA3 & Field CA3, Ammon's horn & NLL & Nucleus of the lateral lemniscus \\
\hline $\mathrm{cc}$ & Corpus callosum & NTB & Nucleus of the trapezoid body \\
\hline CEAI & Central nucleus amygdala, lateral part & och & Optic chiasm \\
\hline CEAm & Central nucleus amygdala, medial part & opt & Optic tract \\
\hline $\mathrm{CL}$ & Central lateral nucleus of thalamus & OVLT & Vascular organ of the lamina terminalis \\
\hline $\mathrm{CM}$ & Central medial nucleus thalamus & PA & Posterior nucleus amygdala \\
\hline Cpd & Cerebral peduncle & PAG & Periaqueductal gray \\
\hline CSI & Superior central nucleus raphe, dorsal part & PBmm & Parabrachial nucleus, medial part \\
\hline $\mathrm{CSm}$ & Superior central nucleus raphe, medial part & $\mathrm{PCN}$ & Paracentral nucleus thalamus \\
\hline cst & Corticospinal tract & $\mathrm{PF}$ & Parafascicular nucleus \\
\hline CUN & Cuneiform nucleus & $\mathrm{PH}$ & Posterior hypothalamic nucleus \\
\hline $\mathrm{dg}$ & Dentate gyrus & PMd & Dorsal premammillary nucleus \\
\hline DGmb & Dentate gyrus, medial blade & $\mathrm{PMv}$ & Ventral premammillary nucleus \\
\hline $\mathrm{DMH}$ & Dorsomedial hypothalamus & POR & Periolivary region \\
\hline DMHa & Dorsomedial hypothalamus, anterior part & PR & Perireuniens nucleus \\
\hline DMHр & Dorsomedial hypothalamus, posterior part & $\mathrm{PRNc}$ & Pontine reticular nucleus \\
\hline DR & Dorsal raphe & $\mathrm{PRNr}$ & Pontine reticular nucleus, rostral part \\
\hline $\mathrm{EPv}$ & Endopiriform nucleus, ventral part & PSV & Principle sensory nucleus of the trigeminal \\
\hline f & Fornix & $\mathrm{PT}$ & Parataenial nucleus \\
\hline fi & Fimbria & Pva & Anterior periventricular nucleus hypothalamus \\
\hline $\begin{array}{l}\text { fr } \\
\text { GPI }\end{array}$ & $\begin{array}{l}\text { Fasciculus retroflexus } \\
\text { Globus pallidus, lateral segment }\end{array}$ & PVHam & $\begin{array}{l}\text { Paraventricular nucleus hypothalamus, anterior } \\
\text { magnocellular part }\end{array}$ \\
\hline
\end{tabular}




\begin{tabular}{|c|c|}
\hline PVHap & $\begin{array}{l}\text { Paraventricular nucleus hypothalamus, anterior par- } \\
\text { vicellular part }\end{array}$ \\
\hline PVHm & $\begin{array}{l}\text { Paraventricular nucleus hypothalamus, magnocellu- } \\
\text { lar division }\end{array}$ \\
\hline PVHp & $\begin{array}{l}\text { Paraventricular nucleus hypothalamus, parvicellular } \\
\text { division }\end{array}$ \\
\hline Pvi & Intermediate periventricular nucleus hypothalamus \\
\hline PVp & Posterior periventricular nucleus hypothalamus \\
\hline PVT & Paraventricular nucleus thalamus \\
\hline $\mathrm{RCH}$ & Retrochiasmatic area \\
\hline $\mathrm{REa}$ & Nucleus reuniens, anterior part \\
\hline $\mathrm{RM}$ & Nucleus raphe magnus \\
\hline RT & Reticular nucleus thalamus \\
\hline rust & Rubospinal tract \\
\hline SAG & Nucleus sagulum \\
\hline SBPV & Subparaventricular zone hypothalamus \\
\hline $\mathrm{SC}$ & Superior colliculus \\
\hline $\mathrm{SCH}$ & Suprachiasmatic nucleus \\
\hline $\operatorname{scp}$ & Superior cerebellar peduncle \\
\hline SF & Septofimbrial nucleus \\
\hline SFO & Subfronical organ \\
\hline $\mathrm{sm}$ & Stria medullaris \\
\hline SMT & Submedial nucleus thalamus \\
\hline SON & Supraoptic nucleus \\
\hline SOr & Supraoptic nucleus, retrochiasmatic part \\
\hline SPFm & $\begin{array}{l}\text { Subparafascicular nucleus thalamus, magnocellular } \\
\text { part }\end{array}$ \\
\hline SPO & Superior paraolivary nucleus \\
\hline st & Stria terminalis \\
\hline STN & Subthalamic nucleus \\
\hline SUT & Supratrigeminal nucleus \\
\hline TRN & Tegmental reticular nucleus, pontine gray \\
\hline TRS & Triangular nucleus septum \\
\hline tsp & Tectospinal pathway \\
\hline TU & Tuberal area hypothalamus \\
\hline $\mathrm{V}$ & Motor nucleus of the trigeminal nerve \\
\hline VAL & Ventral anterior-lateral complex thalamus \\
\hline Vhc & Ventral hippocampal commissure \\
\hline V IIIn & Vestibulocochlear nerve \\
\hline VM & Ventral medial nucleus thalamus \\
\hline VMH & Ventromedial nucleus hypothalamus \\
\hline VMHa & Ventromedial nucleus hypothalamus, anterior part \\
\hline VMHc & Ventromedial nucleus hypothalamus, central part \\
\hline $\begin{array}{l}\text { VM- } \\
\text { Hdm }\end{array}$ & $\begin{array}{l}\text { Ventromedial nucleus hypothalamus, dorsomedial } \\
\text { part }\end{array}$ \\
\hline VMHvl & $\begin{array}{l}\text { Ventromedial nucleus hypothalamus, ventrolateral } \\
\text { part }\end{array}$ \\
\hline VPL & Ventral posterolateral nucleus thalamus \\
\hline VPM & Ventral posteromedial nucleus thalamus \\
\hline $\mathrm{ZI}$ & Zona incerta \\
\hline
\end{tabular}

pattern occupied the lateral edge of the intermediate part of the LS along the lateral ventricle (Fig. 6A). At this level, a few scattered fibers were also observed around the anterior commissure. In the BST, dense Ucn III-IR fibers were found occupying the posterior division (Fig. $4 E, 6 B$ ), whereas very few labeled fibers were observed in the rostral division. In the amygdala (Fig. $6 C$ ), the majority of the Ucn III-IR fibers were observed in the medial nucleus, including both its dorsal and ventral subnuclei. Scattered fibers also extended into the basomedial subnuclei and the posterior cortical nuclei of the amygdala. More caudally, Ucn III-IR fibers extended into the ventral hippocampus (Fig. 6D). In the thalamus, a few scattered fibers were found in the posterior part of the paraventricular nucleus and in the lateral habenula.

In the midbrain and brainstem, scattered fibers were observed in several areas with low levels of CRF-R2 expression (Van Pett et al., 2000). These areas include the dorsal and dorsolateral columns of the periaqueductal gray, the superior and inferior colliculi, and the ventral lateral lemniscus (Fig. 4O). Very few or no fibers were observed in the dorsal raphe, interpeduncular nucleus, area postrema, and the nucleus of the solitary tract, regions with moderate to high levels of CRF-R2 expression.

\section{DISCUSSION}

\section{Ucn III neuronal distribution}

In the present study, Ucn III-expressing neurons were identified by in situ hybridization and immunohistochemistry. The immunostaining was blocked by preabsorbing the antiserum with either mouse or human Ucn III but not by structurally related peptides, including CRF, Ucn, and Ucn II. In addition, the distributions of Ucn III perikarya revealed by the two methods were in close accord, and neither approach produced any evidence of crossreactivity with other known CRF family members (Swanson et al., 1983; Kozicz et al., 1998; Bittencourt et al., 1999). These results thus support the specificity of the localization reported here. The present findings confirm previously reported (Lewis et al., 2001) major sites of Ucn III mRNA expression in the brain, including the $\mathrm{MePO}$ and the rostral perifornical area in the hypothalamus, dorsal division of the MEA, and the auditory complex in the brainstem. Colchicine pretreatment did not reveal additional populations of Ucn III-expressing neurons in the brain.

\section{Ucn III fiber distribution}

As summarized in Figure 4, Ucn III-positive fibers showed a distribution distant from those of CRF and Ucn (Swanson et al., 1983; Kozicz et al., 1998; Bittencourt et al., 1999). An important characteristic of the fiber distribution, shown in Table 3 , is that most of the Ucn III fiber terminal fields in the forebrain also express CRF-R2 (Chalmers et al., 1995; Van Pett et al., 2000). Areas with densest Ucn III innervation include the $\mathrm{VMH}$, the LS, the posterior division of the BST, and the MEA, areas known to express high levels of CRF-R2. The close association between Ucn III terminal fields and the expression of the CRF-R2 supports the notion that Ucn III is an endogenous ligand for CRF-R2 in these areas. In the hindbrain, however, some discrepancy between the distribution of Ucn III fibers and the expression of CRF-R2 was observed. Very few or no Ucn III fibers were found in the dorsal raphe, area postrema, and the nucleus of the solitary tract, regions that contain high levels of CRF-R2 (Chalmers et al., 1995; Van Pett et al., 2000). Interestingly, as summarized in Table 3 , these areas are innervated by Ucn fibers (Bittencourt et al., 1999), suggesting that the endogenous ligand for CRF-R2 in these areas is Ucn rather than Ucn III. Together, the evidence suggests that Ucn III is positioned to serve as a major ligand for CRF-R2 in the forebrain, whereas Ucn mediates the effects of CRF-R2 in the hindbrain. Several brain regions, including the hippocampus and the cortical regions, have been shown to express CRF-R2 (Chalmers et al., 1995; Van Pett et al., 2000) but fail to possess impressive Ucn inputs (Bittencourt et al., 1999) or Ucn III innervations (present study). It is conceivable that another CRF-R2- 

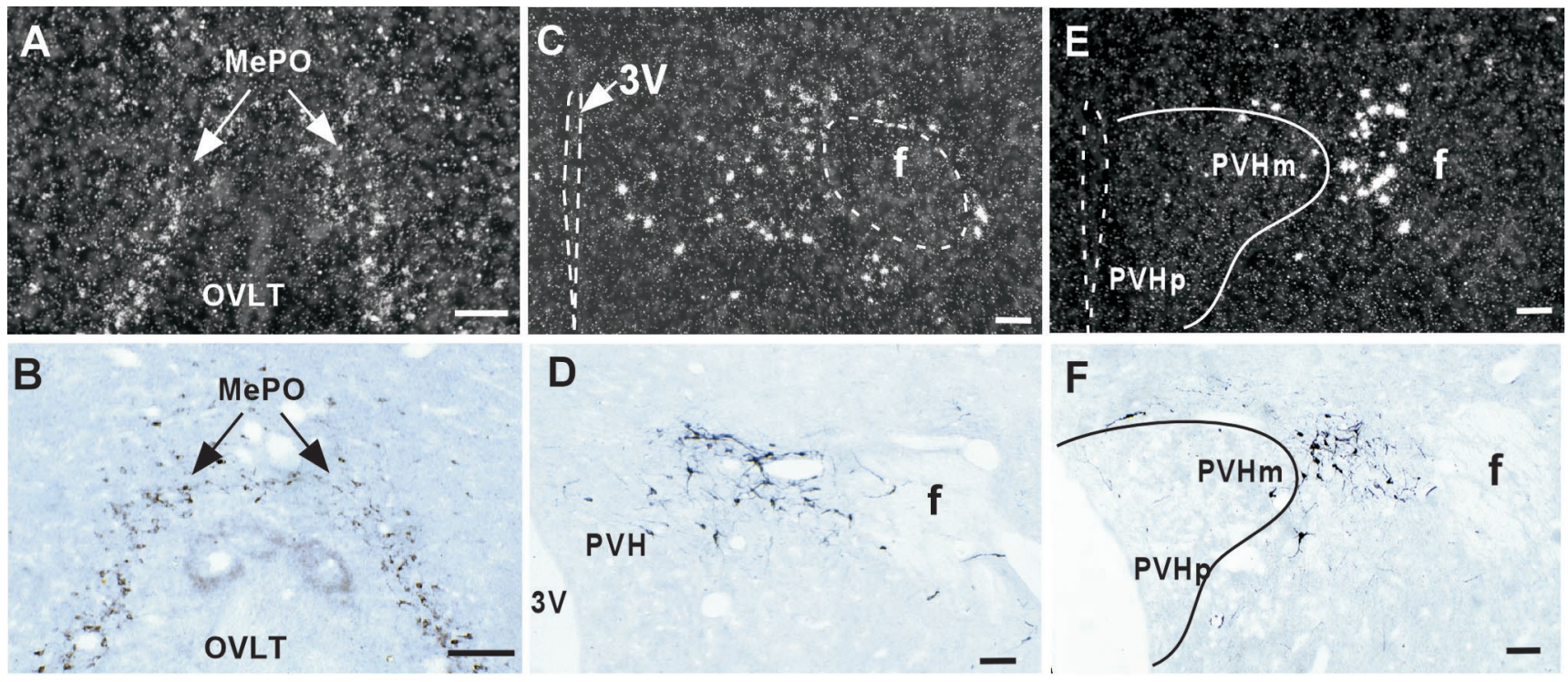

Figure 2. Representative dark-field (left) and bright-field (right) photomicrographs showing the distribution of Ucn III mRNA and Ucn III immunoreactivity, respectively, in selected hypothalamic areas. In the MePO $(A, B)$, both methods detected Ucn III-positive neurons along the midline of the rostral end of the third ventricle. In the rostral perifornical area near the anterior part of the PVH $(C, D)$, both preparations labeled a cluster of cells medial to the fornix. At the level of mid-PVH $(E, F)$, Ucn III neurons were observed medial to the fornix and lateral to the PVH, whereas only a few cells were found inside the PVH. Scale bars, $50 \mu \mathrm{m}$.
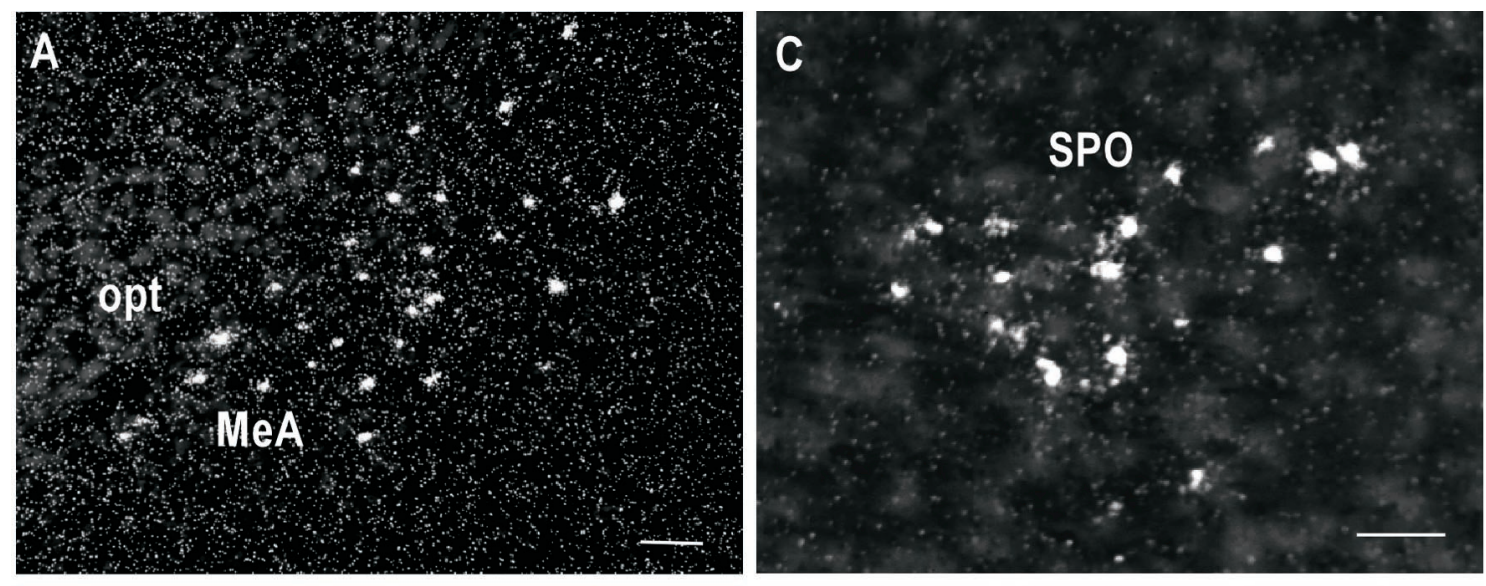

B

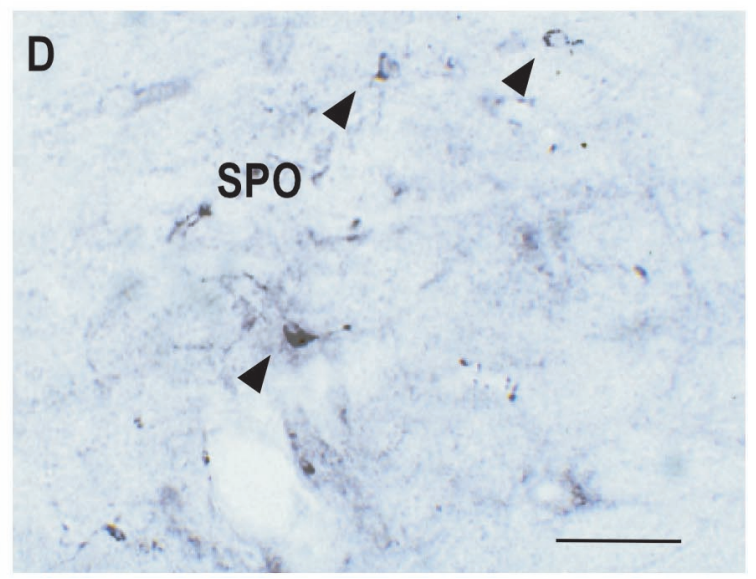

Figure 3. Representative dark-field (left) and bright-field (right) photomicrographs showing Ucn III neurons in the MEA and the superior paraolivary nucleus $(S P O)$ detected by in situ hybridization (left) and immunohistochemistry (right), respectively. In the MEA $(A, B)$, Ucn III-positive neurons were seen closely associated with the optic tract $(o p t)$. In the brainstem $(C, D)$, scattered Ucn cells (arrowheads) were found close to the medial edge of the superior paraolivary nucleus $(E, F)$. Scale bars, $50 \mu \mathrm{m}$. 

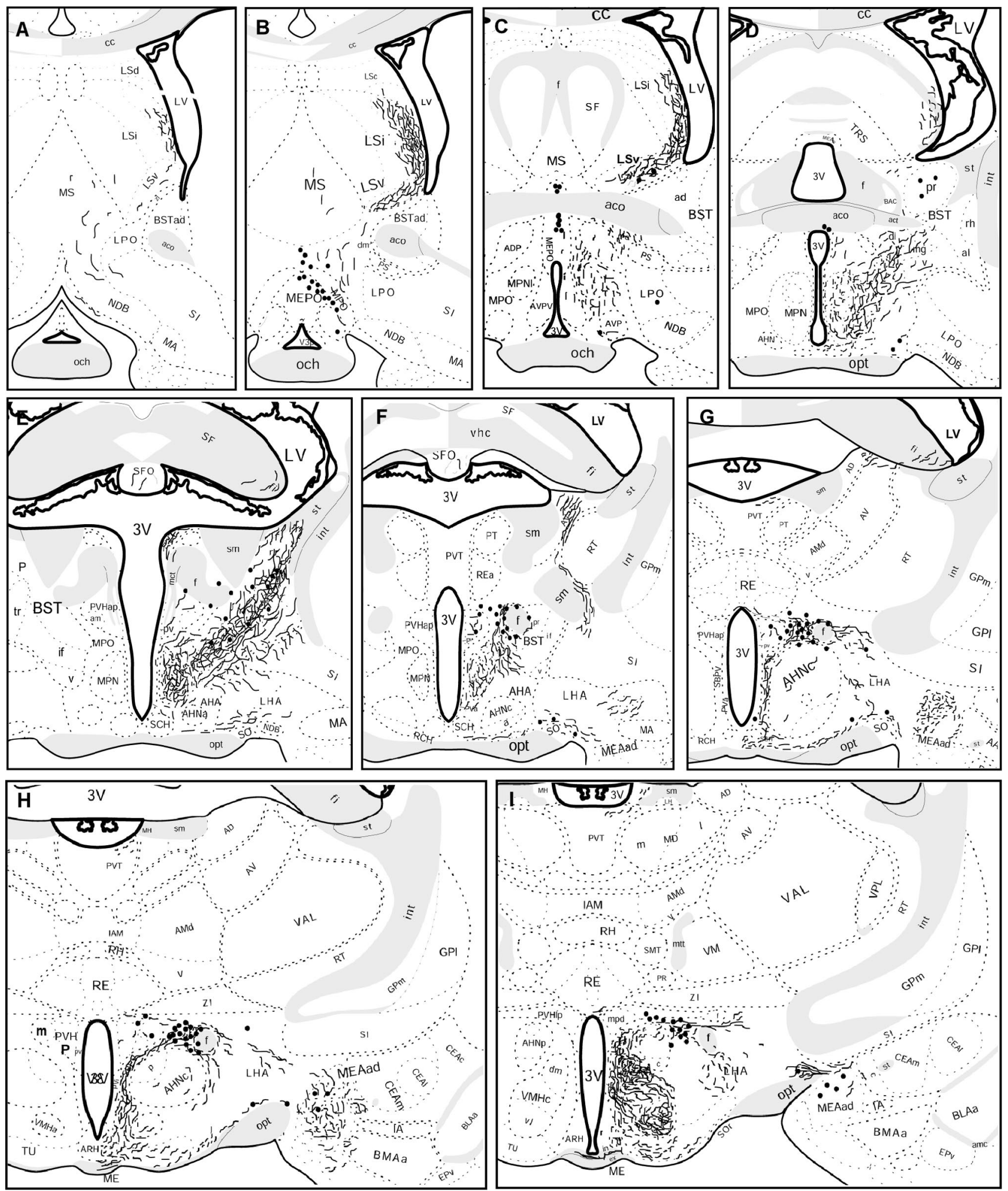

Figure 4. Schematic drawings of $25 \mu \mathrm{m}$ coronal sections showing the distribution of Ucn III-immunoreactive cells bodies (black dots) and fibers in the rat brain. (Figure 4 continues.)

selective ligand, Ucn II, may innervate these areas. A detailed analysis of Ucn II distribution may resolve this issue.

The distribution of Ucn III-IR fibers observed in the present study also appears to confirm the results from anatomical studies demonstrating the projections of major Ucn III cellular expres- sion sites. It has been shown that neurons in the rostral perifornical area project heavily into the LS, the posterior division of the BST, and the VMH (Wiegand and Price, 1980; Kita and Oomura, 1982; Risold et al., 1994). MEA has also been shown to project to the hypothalamus, including the $\mathrm{VMH}$ and the ventral premam- 

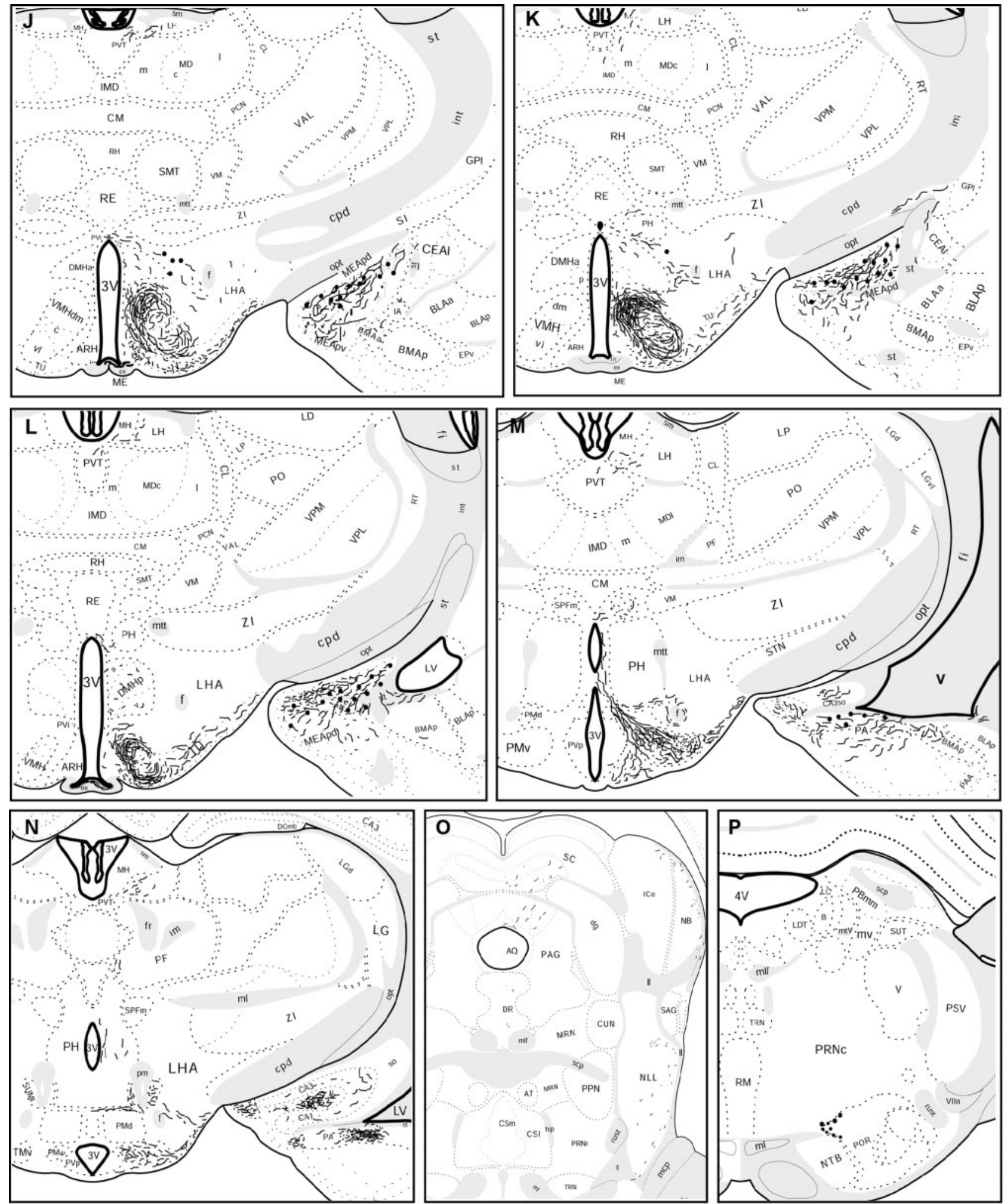

Figure 4 continued.

millary nucleus, as well as to the BST and the amygdala (Canteras et al., 1995). This anatomical data suggests that Ucn III neurons in the perifornical area and the MEA are positioned to provide the majority of the Ucn III innervations in the brain.

It has been shown that the MePO projects heavily to neurose- cretory neurons in the magnocellular part of the PVH and the supraoptic nucleus (Sawchenko and Swanson, 1983; Weiss and Hatton, 1990) and into the circumventricular organs (Camacho and Phillips, 1981; Lind et al., 1982; Oldfield et al., 1992). However, in the present study, only a few Ucn III fibers were observed 

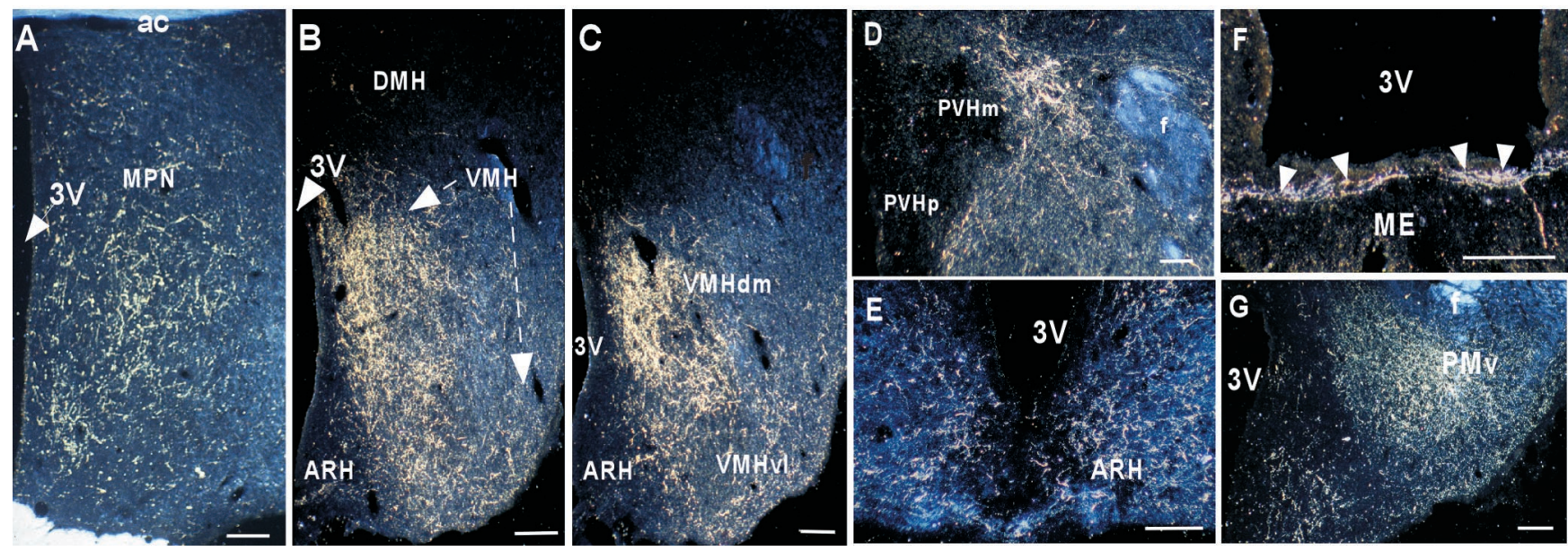

Figure 5. Dark-field photomicrographs showing abundant Ucn III-immunoreactive fibers in discrete hypothalamic areas, including the medial preoptic nucleus $(A)$, the rostral $(B)$ and caudal part $(C)$ of the ventromedial nucleus, the rostral part of the arcuate nucleus $(E)$, and the ventral premammillary nucleus $(G)$, whereas only a few fibers were found in the PVH $(D)$. Also note that only a few scatter fibers were found in the dorsomedial nucleus $(C)$. In the median eminence $(F ; M E)$, Ucn III fibers (indicated by arrowheads) were found only in the internal zone of the median eminence. Scale bar, $50 \mu \mathrm{m}$.
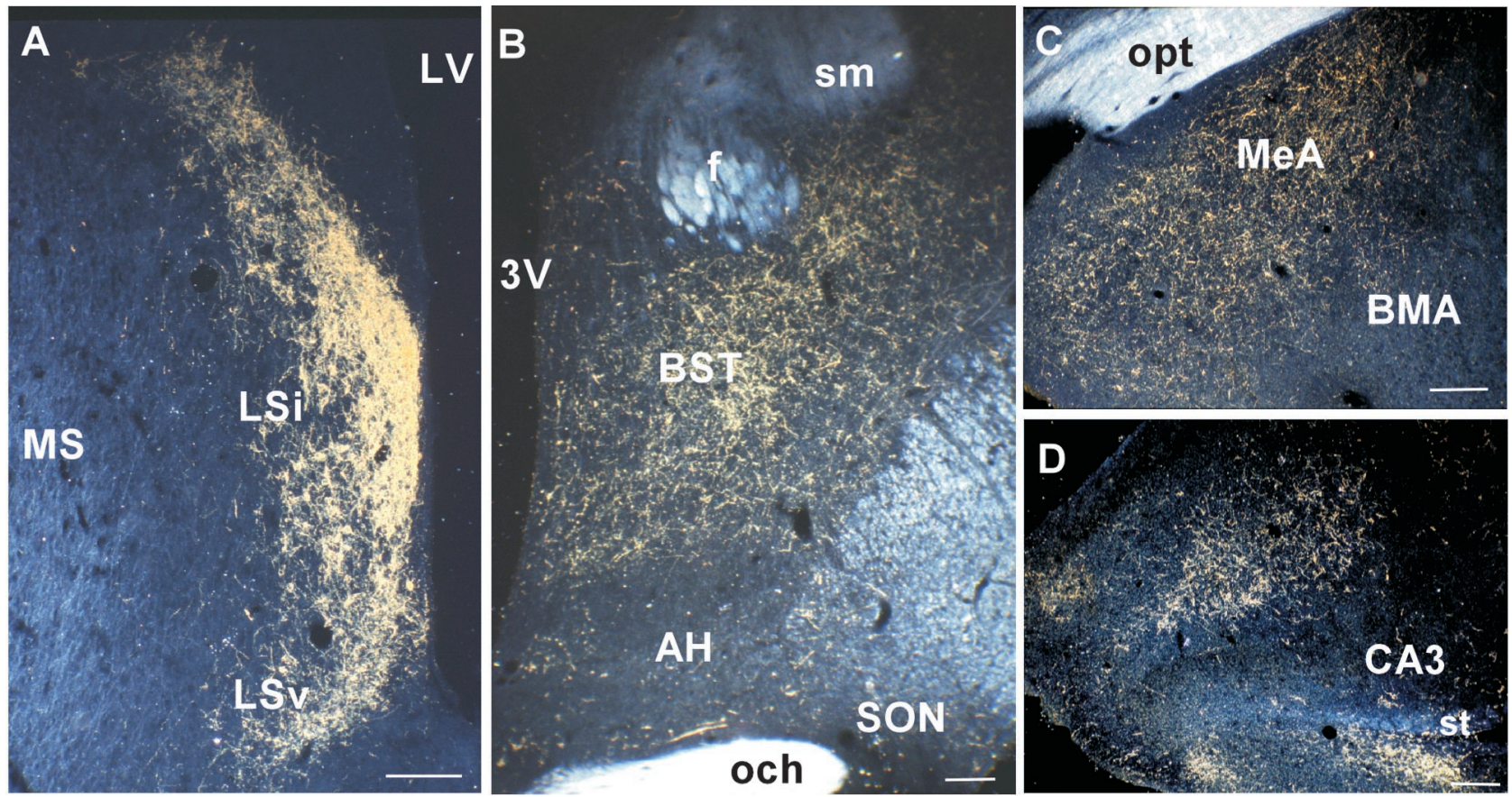

Figure 6. Representative dark-field photomicrographs showing dense Ucn III-immunoreactive fibers in the intermediate ( $L S i)$ and ventral $(L S v)$ parts of the LS $(A)$, the posterior part of the BST $(B)$, the MEA $(C)$, and the caudal part of the hippocampus and amygdaloid areas $(D)$. Note that the rostral portion of the anterior hypothalamus and supraoptic nucleus $(S O N)$ received little Ucn III innervation $(B)$. Scale bars, $50 \mu \mathrm{m}$.

in these areas, although Ucn III-positive cells were found in the MePO. It should be pointed out that the MePO appeared to express relatively low levels of Ucn III mRNA compared with other Ucn III-expressing loci, such the rostral perifornical areas and the medial amygdala. Thus, it is possible that the peptide expression levels in these areas are beneath the level of detectability by the antiserum.

\section{Functional implication of Ucn III in the terminal fields}

The involvement of CRF receptors and their ligands in the regulation of feeding has been extensively studied. Activation of CRF receptors in the brain by central administration of CRF ligands suppresses food intake (Spina et al., 1996; Cullen et al.,
2001). Furthermore, injections of Ucn into the VMH significantly inhibits food intake (Ohata et al., 2000), suggesting that CRF-R2 in the VMH is involved in the regulation of feeding. Several studies have shown that the expression levels of CRF-R2 mRNA in the $\mathrm{VMH}$ are sensitive to the energy status of the animals (Makino et al., 1998; Nishiyama et al., 1999), further supporting the importance of CRF-R2 in the $\mathrm{VMH}$ in regulating energy homeostasis. The majority of the CRF-R2 in the VMH was found in the dorsomedial part of the nucleus (Chalmers et al., 1995; Van Pett et al., 2000), which coincided with the pattern of Ucn III fibers in this nucleus observed in the present study. Thus, Ucn III is likely to be the endogenous ligand in the VMH 


\begin{tabular}{|c|c|c|c|}
\hline Brain region & $\begin{array}{l}\mathrm{Ucn}^{a} \\
\text { fibers }\end{array}$ & $\begin{array}{l}\text { Ucn III } \\
\text { fibers }\end{array}$ & $\begin{array}{c}\text { CRF-R2 }^{b} \\
\text { mRNA }\end{array}$ \\
\hline \multicolumn{4}{|l|}{ Forebrain } \\
\hline \multicolumn{4}{|l|}{ Amygdala } \\
\hline Posterior cortical nucleus & + & +++ & +++ \\
\hline Basolateral nucleus & + & - & + \\
\hline Basomedial nucleus & + & $+/++$ & ++ \\
\hline Central nucleus & + & - & - \\
\hline Medial nucleus & + & +++ & ++ \\
\hline \multicolumn{4}{|l|}{ Septum } \\
\hline Lateral nucleus & +++ & ++++ & ++++ \\
\hline Medial nucleus & $+/++$ & - & - \\
\hline \multicolumn{4}{|l|}{ Bed nucleus, stria terminalis } \\
\hline Rostral region & ++ & + & - \\
\hline Posterior region & + & +++ & ++ \\
\hline \multicolumn{4}{|l|}{ Hypothalamus } \\
\hline Arcuate nucleus & + & ++ & + \\
\hline Medial preoptic nucleus & + & +++ & $+/++$ \\
\hline \multicolumn{4}{|l|}{ Paraventricular nucleus } \\
\hline Parvicellular part & - & + & + \\
\hline Magnocellular part & + & + & + \\
\hline Supraoptic nucleus & + & $-1+$ & ++ \\
\hline Ventromedial nucleus & + & ++++ & +++ \\
\hline \multicolumn{4}{|l|}{ Hindbrain } \\
\hline Area posterma & ++ & - & ++ \\
\hline Dorsal raphe & +++ & $+/-$ & +++ \\
\hline Inferior colliculus & ++ & + & ++ \\
\hline Interpeduncular nucleus & ++ & $+1-$ & +++ \\
\hline Nucleus of the solitary tract & ++ & - & ++ \\
\hline Periaqueductal gray & $++/+++$ & $+/++$ & + \\
\hline
\end{tabular}

${ }^{a}$ Taken from Bittencourt et al., 1999.

${ }^{b}$ Taken from Van Pett et al., 2000.

mediating the effect of CRF-R2. In addition to the VMH, Ucn III fibers were also present in areas such as the arcuate nucleus of the hypothalamus and the posterior amygdalohippocmapal area. These areas not only express CRF-R2 (Van Pett et al., 2000) but are also known to be involved in the regulation of food intake (King et al., 1994; Sawchenko, 1998; Coscina et al., 2000). Together, this data suggests that central Ucn III may regulate feeding by acting through CRF-R2.

It has been shown that the CRF-R2-deficient mice exhibited heightened anxiety levels (Bale et al., 2000; Coste et al., 2000; Kishimoto et al., 2000), suggesting that CRF-R2 is involved in the modulation of anxiety. Other studies have proposed that CRF-R2 in the LS might play an important role in stress-induced anxiety (Radulovic et al., 1999; Ho et al., 2001). Ucn has been considered as a candidate endogenous ligand for CRF-R2 (Kozicz et al., 1998; Bittencourt et al., 1999) in the LS, in which Ucn terminals occupy the medial part of the LS near the medial septum. The present study shows that dense Ucn III fibers were localized in the intermediate and ventral parts of the LS along the lateral ventricle. Thus, Ucn and Ucn III inputs into the LS appear to be organized to occupy different subdivisions of the LS. It is not clear whether the two ligands mediate the same effects or are involved in different functions. Additional studies are needed to elucidate this issue.

Currently, the function of CRF-R2 in the MEA has not been examined in detail. Therefore, it is difficult to predict the function of Ucn III in this region. Anatomical and physiological studies have shown that the MEA is involved in the regulation of neuroendocrine and autonomic nervous system functions (Docke et al., 1983; Pfeiffer and Johnston, 1994; Canteras et al., 1995). In addition, the MEA has been suggested to modulate reproductionrelated behavior (Rajendren and Moss, 1993; Dominguez et al., 2001). Therefore, Ucn III and CRF-R2 in the MEA may play an important role in mediating neuroendocrine status and behaviors.

Similar to the MEA, the ventral premammillary nucleus has been viewed as part of the circuitry involved in neuroendocrine and autonomic regulation (Beltramino and Taleisnik, 1985; Canteras et al., 1992) and in mediating agonistic behavior (Van den Berg et al. 1983; Yokosuka et al., 1999). However, no known CRF receptors have been found in this area (Van Pett et al., 2000), suggesting that either the levels of CRF receptors are very low or can only be detected under certain conditions. In addition, it cannot be ruled out that a new splice variant of known CRF receptors or a new receptor might be present in this area for mediating the actions of Ucn III.

In conclusion, the close association of the identified Ucn III terminal fields with the expression of CRF-R2 in most of brain areas examined strongly suggests that Ucn III is an endogenous ligand for CRF-R2 in these regions. These results also provide an anatomical framework to facilitate an understanding of the function of Ucn III and CRF-R2 in the brain.

\section{REFERENCES}

Bale TL, Contarino A, Smith GW, Chan R, Gold LH, Sawchenko PE, Koob GF, Vale WW, Lee KF (2000) Mice deficient for corticotropinreleasing hormone receptor-2 display anxiety-like behaviour and are hypersensitive to stress. Nat Genet 24:410-414.

Beltramino C, Taleisnik S (1985) Ventral premammillary nuclei mediate pheromonal-induced $\mathrm{LH}$ release stimuli in the rat. Neuroendocrinology 41:119-124.

Bittencourt JC, Vaughan J, Arias C, Rissman RA, Vale WW, Sawchenko PE (1999) Urocortin expression in rat brain: evidence against a pervasive relationship of urocortin-containing projections with targets bearing type 2 CRF receptors. J Comp Neurol 415:285-312.

Brunner B, Grutzner F, Yaspo ML, Ropers HH, Haaf T, Kalscheue VM (2000) Molecular cloning and characterization of the Fugu rubripes MEST/COPG2 imprinting cluster and chromosomal localization in Fugu and Tetraodon nigroviridis. Chromosome Res 8:465-476.

Camacho A, Phillips MI (1981) Horseradish peroxidase study in rat of the neural connections of the organum vasculosum of the lamina terminalis. Neurosci Lett 25:201-204.

Canteras NS, Simerly RB, Swanson LW (1992) Projections of the ventral premammillary nucleus. J Comp Neurol 324:195-212.

Canteras NS, Simerly RB, Swanson LW (1995) Organization of projections from the medial nucleus of the amygdala: a PHAL study in the rat. J Comp Neurol 360:213-245.

Chalmers DT, Lovenberg TW, De Souza EB (1995) Localization of novel corticotropin-releasing factor receptor $\left(\mathrm{CRF}_{2}\right)$ mRNA expression to specific subcortical nuclei in rat brain: comparison with $\mathrm{CRF}_{1}$ receptor mRNA expression. J Neurosci 15:6340-6350.

Coscina DV, Currie PJ, Bishop C, Parker GC, Rollins BL, King BM (2000) Posterodorsal amygdala lesions reduce feeding stimulated by 8-OH-DPAT. Brain Res 883:243-249.

Coste SC, Kesterson RA, Heldwein KA, Stevens SL, Heard AD, Hollis JH, Murray SE, Hill JK, Pantely GA, Hohimer AR, Hatton DC, Phillips TJ, Finn DA, Low MJ, Rittenberg MB, Stenzel P, StenzelPoore MP (2000) Abnormal adaptations to stress and impaired cardiovascular function in mice lacking corticotropin-releasing hormone receptor-2. Nat Genet 24:403-409.

Cullen M, Ling N, Foster A, Pelleymounter M (2001) Urocortin, corticotropin releasing factor-2 receptors, energy balance. Endocrinology 142:992-999.

Docke F, Rohde W, Dorner G (1983) Increase of FSH secretion in immature female rats following lesioning of the medial amygdaloid nucleus. Exp Clin Endocrinol 82:384-387.

Dominguez J, Riolo JV, Xu Z, Hull EM (2001) Regulation by the medial amygdala of copulation and medial preoptic dopamine release. J Neurosci 21:349-355.

Ho SP, Takahashi LK, Livanov V, Spencer K, Lesher T, Maciag C, Smith 
MA, Rohrbach KW, Hartig PR, Arneric SP (2001) Attenuation of fear conditioning by antisense inhibition of brain corticotropin releasing factor-2 receptor. Brain Res Mol Brain Res 89:29-40.

Hsu SY, Hsueh AJ (2001) Human stresscopin and stresscopin-related peptide are selective ligands for the type 2 corticotropin-releasing hormone receptor. Nat Med 7:605-611.

King BM, Sam H, Arceneaux ER, Kass JM (1994) Effect on food intake and body weight of lesions in and adjacent to the posterodorsal amygdala in rats. Physiol Behav 55:963-966.

Kishimoto T, Radulovic J, Radulovic M, Lin CR, Schrick C, Hooshmand F, Hermanson O, Rosenfeld MG, Spiess J (2000) Deletion of crhr2 reveals an anxiolytic role for corticotropin-releasing hormone receptor-2. Nat Genet 24:415-419.

Kita H, Oomura Y (1982) An HRP study of the afferent connections to rat medial hypothalamic region. Brain Res Bull 8:53-62.

Kozicz T, Yanaihara H, Arimura A (1998) Distribution of urocortin-like immunoreactivity in the central nervous system of the rat. J Comp Neurol 391:1-10.

Lewis K, Li C, Perrin MH, Blount A, Kunitake K, Donaldson C, Vaughan J, Reyes TM, Gulyas J, Fischer W, Bilezikjian L, Rivier J, Sawchenko PE, Vale WW (2001) Identification of urocortin III, an additional member of the corticotropin-releasing factor (CRF) family with high affinity for the CRF2 receptor. Proc Natl Acad Sci USA 98:7570-7575.

Li C, Chen P, Smith MS (1998) The acute suckling stimulus induces expression of neuropeptide Y (NPY) in cells in the dorsomedial hypothalamus and increases NPY expression in the arcuate nucleus. Endocrinology 139:1645-1652.

Lind RW, Van Hoesen GW, Johnson AK (1982) An HRP study of the connections of the subfornical organ of the rat. J Comp Neurol 210:265-277.

Makino S, Nishiyama M, Asaba K, Gold PW, Hashimoto K (1998) Altered expression of type $2 \mathrm{CRH}$ receptor mRNA in the VMH by glucocorticoids and starvation. Am J Physiol 275:R1138-R1145.

Martinez V, Tache Y (2001) Role of CRF receptor 1 in central CRFinduced stimulation of colonic propulsion in rats. Brain Res 893:29-35.

Martinez V, Rivier J, Wang L, Tache Y (1997) Central injection of a new corticotropin-releasing factor (CRF) antagonist, astressin, blocks CRFand stress-related alterations of gastric and colonic motor function. J Pharmacol Exp Ther 280:754-760.

Nishiyama M, Makino S, Asaba K, Hashimoto K (1999) Leptin effects on the expression of type-2 CRH receptor mRNA in the ventromedial hypothalamus in the rat. J Neuroendocrinol 11:307-314.

Ohata H, Suzuki K, Oki Y, Shibasaki T (2000) Urocortin in the ventromedial hypothalamic nucleus acts as an inhibitor of feeding behavior in rats. Brain Res 861:1-7.

Oldfield BJ, Hards DK, McKinley MJ (1992) Neurons in the median preoptic nucleus of the rat with collateral branches to the subfornical organ and supraoptic nucleus. Brain Res 586:86-90.

Perrin MH, Vale WW (1999) Corticotropin releasing factor receptors and their ligand family. Ann NY Acad Sci 885:312-328.

Pfeiffer CA, Johnston RE (1994) Hormonal and behavioral responses of male hamsters to females and female odors: roles of olfaction, the vomeronasal system, and sexual experience. Physiol Behav 55:129-138.

Radulovic J, Ruhmann A, Liepold T, Spiess J (1999) Modulation of learning and anxiety by corticotropin-releasing factor (CRF) and stress: differential roles of CRF receptors 1 and 2. J Neurosci 19:5016-5025.

Rajendren G, Moss RL (1993) The role of the medial nucleus of amygdala in the mating-induced enhancement of lordosis in female rats: the interaction with luteinizing hormone-releasing hormone neuronal system. Brain Res 617:81-86.

Reyes TM, Lewis K, Perrin MH, Kunitake KS, Vaughan J, Arias CA, Hogenesch JB, Gulyas J, Rivier J, Vale WW, Sawchenko PE (2001) Urocortin II: a member of the corticotropin-releasing factor (CRF) neuropeptide family that is selectively bound by type 2 CRF receptors. Proc Natl Acad Sci USA 98:2843-2848.

Risold PY, Canteras NS, Swanson LW (1994) Organization of projections from the anterior hypothalamic nucleus: a Phaseolus vulgarisleucoagglutinin study in the rat. J Comp Neurol 348:1-40.

Sawchenko PE (1998) Toward a new neurobiology of energy balance, appetite, and obesity: the anatomists weigh in. J Comp Neurol 402:435-441.

Sawchenko PE, Swanson LW (1983) The organization of forebrain afferents to the paraventricular and supraoptic nuclei of the rat. J Comp Neurol 218:121-144.

Spina M, Merlo-Pich E, Chan RKW, Basso AM, Rivier J, Vale W, Koob GF (1996) Appetite-suppressing effects of urocortin, a CRF-related neuropeptide. Science 273:1561-1564.

Swanson LW (1999) Brain maps: structure of the rat brain. New York: Elsevier.

Swanson LW, Sawchenko PE, Rivier J, Vale WW (1983) Organization of ovine corticotropin-releasing factor immunoreactive cells and fibers in the rat brain: an immunohistochemical study. Neuroendocrinology 36:165-186.

Van den Berg MJ, Ter Horst GJ, Koolhaas JM (1983) The nucleus of premammillaris ventralis (PMV) and aggressive behavior in the rat. Aggress Behav 9:41-47.

Van Pett K, Viau V, Bittencourt JC, Chan RK, Li HY, Arias C, Prins GS, Perrin M, Vale W, Sawchenko PE (2000) Distribution of mRNAs encoding CRF receptors in brain and pituitary of rat and mouse. J Comp Neurol 428:191-212.

Vaughan J, Donaldson C, Bittencourt J, Perrin MH, Lewis K, Sutton S, Chan R, Turnbull AV, Lovejoy D, Rivier C, Rivier J, Sawchenko PE, Vale W (1995) Urocortin, a mammalian neuropeptide related to fish urotensin I and to corticotropin-releasing factor. Nature 378:287-292.

Weiss ML, Hatton GI (1990) Collateral input to the paraventricular and supraoptic nuclei in rat. I. Afferents from the subfornical organ and the anteroventral third ventricle region. Brain Res Bull 24:231-238.

Wiegand SJ, Price JL (1980) Cells of origin of the afferent fibers to the median eminence in the rat. J Comp Neurol 192:1-19.

Yokosuka M, Matsuoka M, Ohtani-Kaneko R, Iigo M, Hara M, Hirata K, Ichikawa M (1999) Female-soiled bedding induced fos immunoreactivity in the ventral part of the premammillary nucleus (PMv) of the male mouse. Physiol Behav 68:257-261. 